\title{
Molecular divergence in the timeless and cpr genes among three sympatric cryptic species of the Anopheles triannulatus complex
}

\author{
Teresa Fernandes Silva-do-Nascimento ${ }^{1 /+}$, Luisa Damazio Rona Pitaluga ${ }^{3}$, \\ Alexandre Afranio Peixoto², Ricardo Lourenço-de-Oliveira ${ }^{1}$ \\ 'Laboratório de Transmissores de Hematozoários ²Laboratório de Biologia Molecular de Insetos, \\ Instituto Oswaldo Cruz-Fiocruz, Av. Brasil 4365, 21045-900 Rio de Janeiro, RJ, Brasil \\ ${ }^{3}$ Universidade Federal do Rio de Janeiro/Polo de Xerém, Estrada de Xerém 27, Duque de Caxias, RJ, Brasil
}

Anopheles triannulatus s.l. is a malaria vector with a wide geographic distribution, ranging from Argentina-Nicaragua and Trinidad. Here we analysed sequences of two genes, timeless and $\mathrm{cpr}$, to assess the genetic variability and divergence among three sympatric cryptic species of this complex from Salobra, central-western Brazil. The timeless gene sequences did not conclusively differentiate Anopheles halophylus and An. triannulatus species " $C$ ". However, a partial separation has been observed between these species and An. triannulatus s.s. Importantly, the analysis of the cpr gene sequences revealed fixed differences, no shared polymorphisms and considerable genetic differentiation among the three species of the An. triannulatus complex. The results confirm that An. triannulatus s.s., An. halophylus and An. triannulatus species $C$ are distinct taxa, with the latter two likely representing a more recent speciation event.

Key words: Anopheles triannulatus - Anopheles halophylus - cpr gene - timeless gene - species complex

Anopheles (Nyssorhynchus) triannulatus s.l. has a wide geographic distribution ranging from ArgentinaNicaragua and Trinidad (Faran \& Linthicum 1981, Silva-do-Nascimento \& Lourenço-de-Oliveira 2002, Chadee \& Wilkerson 2005, Silva-do-Nascimento et al. 2006). Although An. triannulatus s.l. is considered zoophilic in most of its territory, it may bite humans indoors and close to houses. It is believed to be a malaria vector when at present at high population densities (Charlwood \& Wilkes 1981, Rubio-Palis 1994). Natural infection by Plasmodium falciparum and Plasmodium vivax s.l. has been reported for An. triannulatus s.l. (Oliveira-Ferreira et al. 1990, Tadei \& Dutary-Thatcher 2000, Póvoa et al. 2001, Galardo et al. 2007).

Morphological and molecular studies on An. triannulatus s.l. from several sites in South America revealed the existence of three distinct sympatric cryptic species only in Salobra, central-western Brazil: An. triannulatus s.s. (Neiva \& Pinto 1922), Anopheles halophylus (Silvado-Nascimento \& Lourenço-de-Oliveira 2002) and An. triannulatus species C (Silva-do-Nascimento \& Lourenço-de-Oliveira 2002, 2007, Silva-do-Nascimento et al. 2006). Genetic variability analysis among these sympatric species using allozymes and random amplification of polymorphic DNA (RAPD) detected a barrier to gene flow among them and corroborated their status as sepa-

Financial support: Fiocruz/CNPq (400271/2006-0/PAPES IV), HHMI, FAPERJ, CNPq

+Corresponding author: tsilva@ioc.fiocruz.br

Received 29 April 2011

Accepted 6 July 2011 rate species and also showed that $A n$. halophylus and $A n$. triannulatus species $\mathrm{C}$ are more closely related to each other than to An. triannulatus s.s. (Silva-do-Nascimento et al. 2006). In addition, analysis of the population density dynamics in central-western Brazil revealed greater differences between An. triannulatus s.s. and An. halophylus/An. triannulatus species $\mathrm{C}$ than between the latter two species, suggesting that the genetic divergence is correlated with differences in larval exploitation and spatial segregation (Silva-do-Nascimento \& Lourençode-Oliveira 2007). Additionally, slight differences were observed in the peak time periods of biting activity at sunset among the three sympatric species in Salobra. Roughly, An. triannulatus s.s. and An. triannulatus C peak after sunset, while An. halophylus bites almost as frequently early as late in the evening. However, during the peak season, An. halophylus and An. triannulatus C appear to present higher frequencies just after sunset, while An. triannulatus s.s. is caught in similar numbers just after sunset and in the evening (Silva-do-Nascimento \& Lourenço-de-Oliveira 2007). These interspecific biting time differences are hypothesised to be under the control of the endogenous circadian clock.

The circadian clock controls several important biological activities, including mating rhythms, which may be involved in temporal reproductive isolation between closely related species (Sakai \& Ishida 2001, Tauber et al. 2003). The molecular control of circadian rhythms involves several clock genes (Hardin 2005), among them timeless (Myers et al. 1995). Rona et al. (2009) found genetic variation in the timeless gene that was useful for distinguishing two cryptic species among Brazilian populations in the Anopheles cruzii complex of the subgenus Kerteszia. Additionally, their results suggested that populations of An. cruzii from South and Southeast Brazil also constitute distinct incipient species of this complex. 
The cpr gene has been successfully used as a molecular marker in the study of the An. cruzii complex (Rona et al. 2010). $c p r$ encodes the enzyme NADH-cytochrome P450 reductase (CPR) and has been sequenced in several insect species (Koener et al. 1993, Hovemann et al. 1997, Nikou et al. 2003). CPR is encoded by a singlecopy gene that is located on chromosome $\mathrm{X}$ in Anopheles gambiae (Nikou et al. 2003). The cytochrome P450 gene family is involved in metabolic insecticide resistance and requires CPR to function. Apart from its previously reported functions, cytochrome P450 enzymes were found to play a role in the regulation of sex-specific gene expression in Drosophila melanogaster (Kasai \& Tomita 2003). P450 exclusive expression in only one sex can have important roles in hormone metabolism and sexual behaviour (Wen \& Scott 2001). Studies conducted on the expression of CPR showed a high mRNA expression in the antenna, suggesting a probable function in olfactory clearance in Drosophila (Hovemann et al. 1997 ) and in the moth Mamestra brassicae (MaibecheCoisne et al. 2005). Olfactory cues are important environmental stimuli affecting mosquito behaviour, playing significant roles not only in the location of oviposition sites and food sources, but also in mating. Therefore, genes involved in the regulation of antennal responses to pheromones are potentially important in sexual isolation between closely related species.

In the present work, we analysed partial fragments of both timeless and cpr to assess the genetic variability and divergence between three sympatric cryptic species of the An. triannulatus complex in Brazil.

\section{MATERIALS AND METHODS}

Mosquito collection - The mosquitoes used in this study were females from Salobra $\left(20^{\circ} 12^{\prime} 40^{\prime \prime} S\right.$, $56^{\circ} 29^{\prime} 30^{\prime}$ 'W), municipality of Miranda, Mato Grosso do Sul. Blood-fed females were collected from horse bait between 5:00-8:00 pm in 1996 and 1997. Mosquitoes were identified on the basis of morphological characteristics of male genitalia, larva and egg, and allozyme patterns (Consoli \& Lourenço-de-Oliveira 1994, Silvado-Nascimento \& Lourenço-de-Oliveira 2002, Silva-doNascimento et al. 2006). Six specimens of each species [An. triannulatus s.s. (ATSB), An. halophylus (AHSB), An. triannulatus species C (SNSB)] were analysed. Analyses of gene sequences were performed by using a single female from each progeny of each field-collected female (where morphological and molecular analysis of the progeny allowed specific identification).

DNA extraction, polymerase chain reaction (PCR) and sequencing of the timeless and cpr fragments in An. triannulatus s.l. - Genomic DNA was extracted individually from females following Jowett (1998). The initial timeless gene fragment was isolated from An. triannulatus s.s. using a pair of specific primers based on a fragment of the Anopheles darlingi timeless gene (forward-5, darltim02a and reverse-3' darltim03) (C Gentile \& AA Peixoto, unpublished observations) (Table I). PCR was performed in an Eppendorf Mastercycler thermocycler using the following cycling conditions: 15 cycles at $94^{\circ} \mathrm{C}$ for $60 \mathrm{~s}, 55^{\circ} \mathrm{C}$ (decreasing $1^{\circ} \mathrm{C} /$ cycle) for $90 \mathrm{~s}$ and $72^{\circ} \mathrm{C}$ for $60 \mathrm{~s}$, followed by 20 cycles of $94^{\circ} \mathrm{C}$ for $60 \mathrm{~s}, 50^{\circ} \mathrm{C}$
TABLE I

Sequence of primers used to amplify the timeless and cpr gene fragments

\begin{tabular}{lc}
\hline Primers & Sequences of primers at 5' $\rightarrow$ 3' \\
\hline 5'darltim02a & GAACGCAGGTCGAGAAGGAATC (forward) \\
3'darltim03 & TCGTTACCGTTTAGCTATTT (reverse) \\
5'timtri & CATTTCGACCTCGAGCAA (forward) \\
3'timtri & CTCTTAAGTGCCAGCTGAA (reverse) \\
5'Cpr01deg & ATGAARGGNATGGTNGCNGA (forward) \\
3'Cpr01deg & ATCCARTCRTARAAYTCCAT (reverse) \\
\hline
\end{tabular}

degenerate and specific primers used to amplify the timeless and cpr loci fragments in all Anopheles triannulatus populations.

for $90 \mathrm{~s}$ and $72^{\circ} \mathrm{C}$ for $60 \mathrm{~s}$. The obtained products were then purified and cloned with the Zero Blunt TOPO PCR cloning it (Invitrogen). Sequencing of positive clones was performed in an ABI Prism 3730 DNA sequencer at the Oswaldo Cruz Institute using the ABI Prism BigDye Terminator Cycle Sequencing Ready Reaction Kit (Applied Biosystems). The identity of the cloned fragments was confirmed by BlastX analysis using the GenBank database. After checking the sequence identity, two new specific primers named 5'timtri and 3'timtri (Table I) were designed and used to amplify a $\sim 310 \mathrm{bp}$ fragment of the An. triannulatus timeless gene. To obtain fragments of the An. triannulatus cpr gene, a pair of degenerate primers (5'CprO1deg and 3'CprO1deg) (Rona et al. 2010) were used (Table I) to amplify a $\sim 210 \mathrm{bp}$ fragment of the An. triannulatus cpr gene. The fragments of both genes include intron sequences.

The primer pairs 5'timtri x 3'timtri and 5'Cproldeg x 3'Cproldeg were used to analyse the An. triannulatus populations (Table I). The PCR reactions for all populations were carried out using an Eppendorf Mastercycler thermocycler according to the following cycling conditions: hold at $94^{\circ} \mathrm{C}$ for $5 \mathrm{~min}, 35$ cycles at $94^{\circ} \mathrm{C}$ for $30 \mathrm{~s}$, $55^{\circ} \mathrm{C}$ (timeless) or $60^{\circ} \mathrm{C}(\mathrm{cpr})$ for $60 \mathrm{~s}$ and $72^{\circ} \mathrm{C}$ for $90 \mathrm{~s}$, using the proofreading $P f u$ DNA polymerase (Biotools). A negative control template (water) was included in all PCR assays. PCR products were purified using Wizard SV Gel and PCR Clean-Up system (Promega) or QIAquick PCR Purification Kit protocol (Qiagen) and cloned with either the Zero Blunt TOPO PCR (Invitrogen) or pMOSBlue Blunt-Ended Cloning Kit (GE Healthcare). Eight clones of each individual were sequenced as described above to identify possible PCR induced errors and to identify the two alleles. In some cases only one haplotype (SNSB) was observed among the eight sequences and the individuals were considered homozygotes. The probability of classifying a heterozygote as a homozygote is less than $1 \%$ using this method.

Sequence analysis - DNA sequences were aligned using the Clustal program (Thompson et al. 1997). Analyses of polymorphisms and differentiation among populations were performed using DnaSP (Rozas et al. 2003) and PROSEQ (Filatov \& Charlesworth 1999) software. MEGA 3.0 was used to perform the genealogical analysis of the sequences obtained (Kumar et al. 2004). 


\section{RESULTS}

A total of 36 nucleotide sequences of the timeless gene fragment from the three species of the An. triannulatus complex were analysed: 12 from each species (ATSB, AHSB and SNSB). The same number was obtained from each species for the cpr locus. The sequences were submitted to GenBank (accessions JN099312 and JN099383). Alignment of the DNA sequences for both genes was performed (Supplementary data) and used in all sequence analysis. All base substitutions were either silent or occurred in the intron.

AHSB and SNSB showed the lowest degree of polymorphism in both timeless and $c p r$, with the lower number of polymorphic sites ( 2 and 1 for timeless and 1 and 0 for $c p r$, respectively) (Table II). In addition, no shared polymorphisms and some fixed differences (7 for ATSB $\mathrm{x}$ AHSB, 5 for ATSB x SNSB, 2 for AHSB x SNSB) were found in cpr (Table II).

Fig. 1 shows a neighbour-joining tree using the timeless sequences. The results were not conclusive for the separation between AHSB and SNSB, clustering these two samples. Nonetheless, a partial separation was observed between the sequences of the AHSB/SNSB cluster and ATSB (Fig. 1). In contrast, the neighbour-joining tree obtained for the cpr sequences showed a clear separation among the three sympatric populations from Salobra, consistent with the fixation index $\left(F_{S T}\right)$ values (Fig. 2).

\section{DISCUSSION}

An. triannulatus s.l. displays a high degree of morphological variation (Galvão 1941, Forattini 1962, Silva-doNascimento \& Lourenço-de-Oliveira 2002). In addition to morphological variation, previous studies have shown that this malaria vector presents polymorphisms in molecular markers and exhibits behavioural variation, suggesting that it is in fact a complex of cryptic species (Santos et al. 1992, 2003, 2004, Rosa-Freitas et al. 1998, Silva-doNascimento \& Lourenço-de-Oliveira 2002, 2007).
The taxonomic status of the members of the $A n$. triannulatus complex was reevaluated with molecular markers (Silva-do-Nascimento et al. 2006) and morphological characters (Silva-do-Nascimento \& Lourençode-Oliveira 2002). Silva-do-Nascimento et al. (2006) suggested the existence of at least three distinct taxa occurring in sympatry in Salobra: An. triannulatus s.s., An. halophylus and An. triannulatus species C. The first two have been characterised (Silva-do-Nascimento \& Lourenço-de-Oliveira 2002, Silva-do-Nascimento et al. 2006), but the last remains to be formally described.

Some interesting particularities emerged from studies of these three sympatric cryptic species. Subtle differences regarding the peak hematophagy period and larval habitat preferences, as those verified during the collections in Salobra (Silva-do-Nascimento \& Lourenço-de-Oliveira 2007), are putative behavioural differences in sympatric incipient species that can reduce gene flow and trigger the speciation process (Diabaté et al. 2005). Timeless and cpr are genes associated with behaviour and are potentially useful tools in population genetic studies and to separate closely related species. Therefore, we used these two molecular markers to study the genetic differentiation among these three sympatric species of the An. triannulatus complex.

Although the timeless gene sequences did not differentiate An. halophylus and An. triannulatus species $\mathrm{C}$, the $F_{S T}$ values were moderately high and significant in the other comparisons (ATSB $x$ AHSB and ATSB $x$ $\mathrm{SNSB}$ ). In addition, when using the $c p r$ gene, very high and significant $F_{S T}$ values were detected among the sympatric An. triannulatus species, revealing considerable genetic differentiation in the An. triannulatus complex. In addition, fixed differences and no shared polymorphisms were found in the $c p r$ sequences among the three populations. AHSB and SNSB were the least polymorphic populations, showing a very low number of haplotypes. Therefore, considering the small sample sizes, the

TABLE II

Genetic differentiation among Anopheles triannulatus s.l. populations from Salobra, central-western Brazil, in the timeless and cpr genes

\begin{tabular}{lcccccccc}
\hline Locus & Populations & $F_{S T}$ & $S_{s}$ & $S_{f}$ & $S_{1}$ & $S_{2}$ & $D x y$ & $D a$ \\
\hline \multirow{2}{*}{ timeless } & ATSB x AHSB & $0.50000^{a}$ & 00 & 00 & 09 & 02 & 0.01079 & 0.00539 \\
& ATSB x SNSB & $0.51818^{a}$ & 00 & 00 & 09 & 01 & 0.01079 & 0.00559 \\
\multirow{4}{*}{$\mathrm{cpr}$} & AHSB x SNSB & -0.06364 & 01 & 00 & 01 & 00 & 0.00179 & -0.00011 \\
& ATSB x AHSB & $0.91103^{a}$ & 00 & 07 & 04 & 01 & 0.03821 & 0.03481 \\
& ATSB x SNSB & $0.91180^{a}$ & 00 & 05 & 04 & 00 & 0.02724 & 0.02483 \\
& AHSB x SNSB & $0.90909^{a}$ & 00 & 02 & 01 & 00 & 0.01098 & 0.00998 \\
\hline
\end{tabular}

a: $\mathrm{p}<0.001$; AHSB: Anopheles halophylus; ATSB: An. triannulatus s.s.; Da: number of net nucleotide substitutions per site between populations; Dxy: average number of nucleotide substitutions per site between populations; fixation index $\left(F_{S T}\right)$ : pair-wise estimates of population differentiation (significance of $F_{S T}$ values evaluated by 1,000 random permutations); $S$ : polymorphic sites; SNSB: An. triannulatus species C; $S_{1}$ : number of $S$ exclusive to the first population shown in the first column; $S_{2}$ : number of $S$ exclusive to the second population shown in the first column; $S_{f}$ : number of fixed differences between the two populations; $S_{s}$ : number of shared polymorphisms between the two populations. 
observed high $F_{S T}$ values have to be regarded with some caution. Nevertheless, as mentioned above, the $F_{S T}$ values are significant in all comparisons, except between AHSB x SNSB using the timeless gene.

The lower degree of polymorphism found in $A n$. halophylus and An. triannulatus species C populations and the higher variability of An. triannulatus s.s., for both timeless and $c p r$, corroborated previous studies using different markers (allozymes and RAPD) (Silvado-Nascimento et al. 2006). A study using 11 allozyme loci to analyse the three sympatric populations of the An. triannulatus complex from Salobra showed that the enzyme mannose phosphate isomerase is a diagnostic locus (Silva-do-Nascimento et al. 2006). The analysis indicated no gene flow among these populations at this

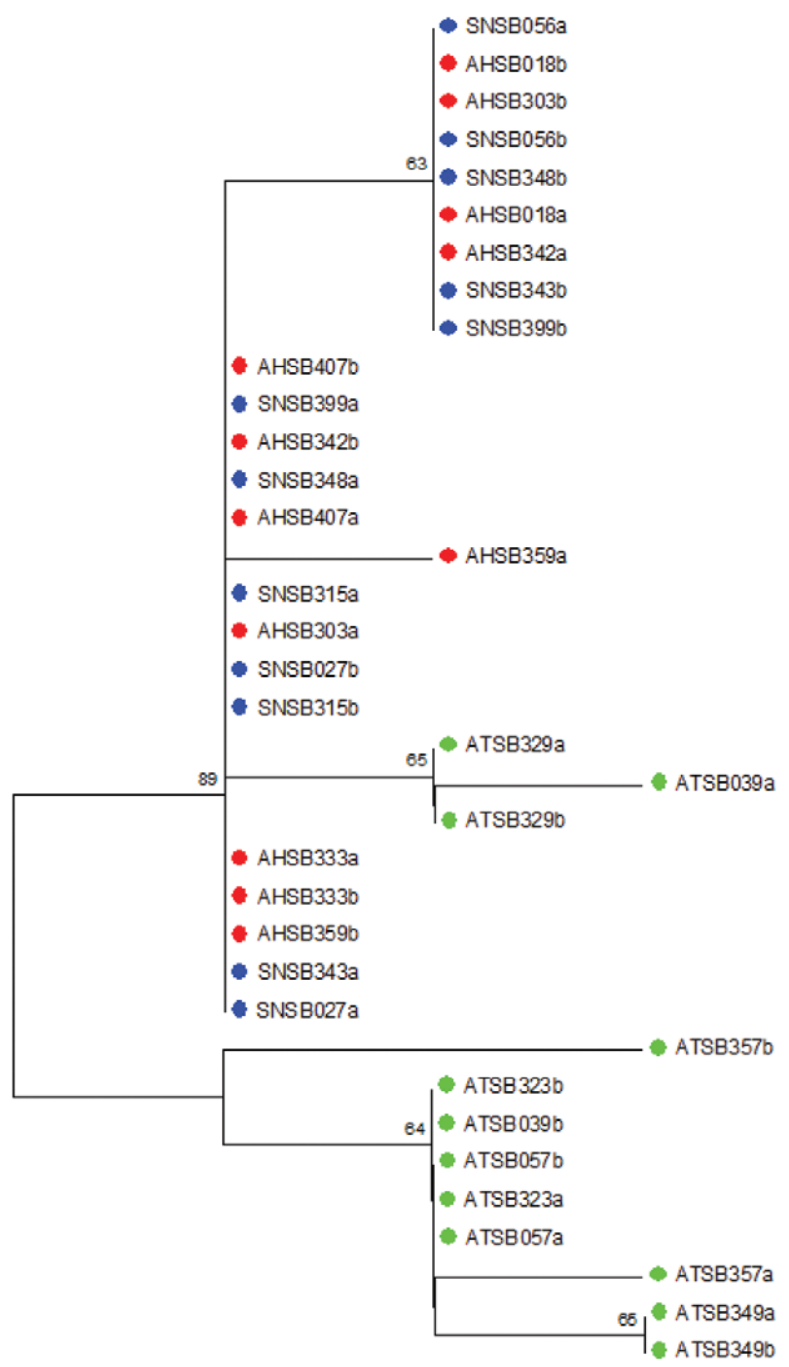

$$
\stackrel{\longmapsto}{0.001}
$$

Fig. 1: neighbor-joining tree of the timeless DNA sequences. The figure shows a neighbour-joining tree based on Anopheles triannulatus s.l. sequences of the timeless gene obtained with Kimura twoparameters distance. Numbers on the nodes represent the percentage bootstrap values based on 1,000 replications. AHSB: Anopheles halophylus (red dot); ATSB: An. triannulatus s.s. (green); SNSB: An. triannulatus species C (blue). locus, as seems to be the case of cpr. The lower divergence found in the analysis of timeless might reflect the persistence of ancestral polymorphisms or introgression in some parts of the genome, indicating that a low level of gene flow might still occur or have occurred in the recent past, as observed, for example, in the An. gambiae complex (Wang-Sattler et al. 2007).

The present study confirms that An. triannulatus s.s. is more polymorphic than both An. halophylus and An. triannulatus species C that An. halophylus and An.triannulatus species $\mathrm{C}$ are more closely related to each other than to An. triannulatus s.s. and, finally, that An. triannulatus s.s., An. halophylus and An. triannulatus species $\mathrm{C}$ are distinct taxa, with the last two likely representing a more recent speciation event.

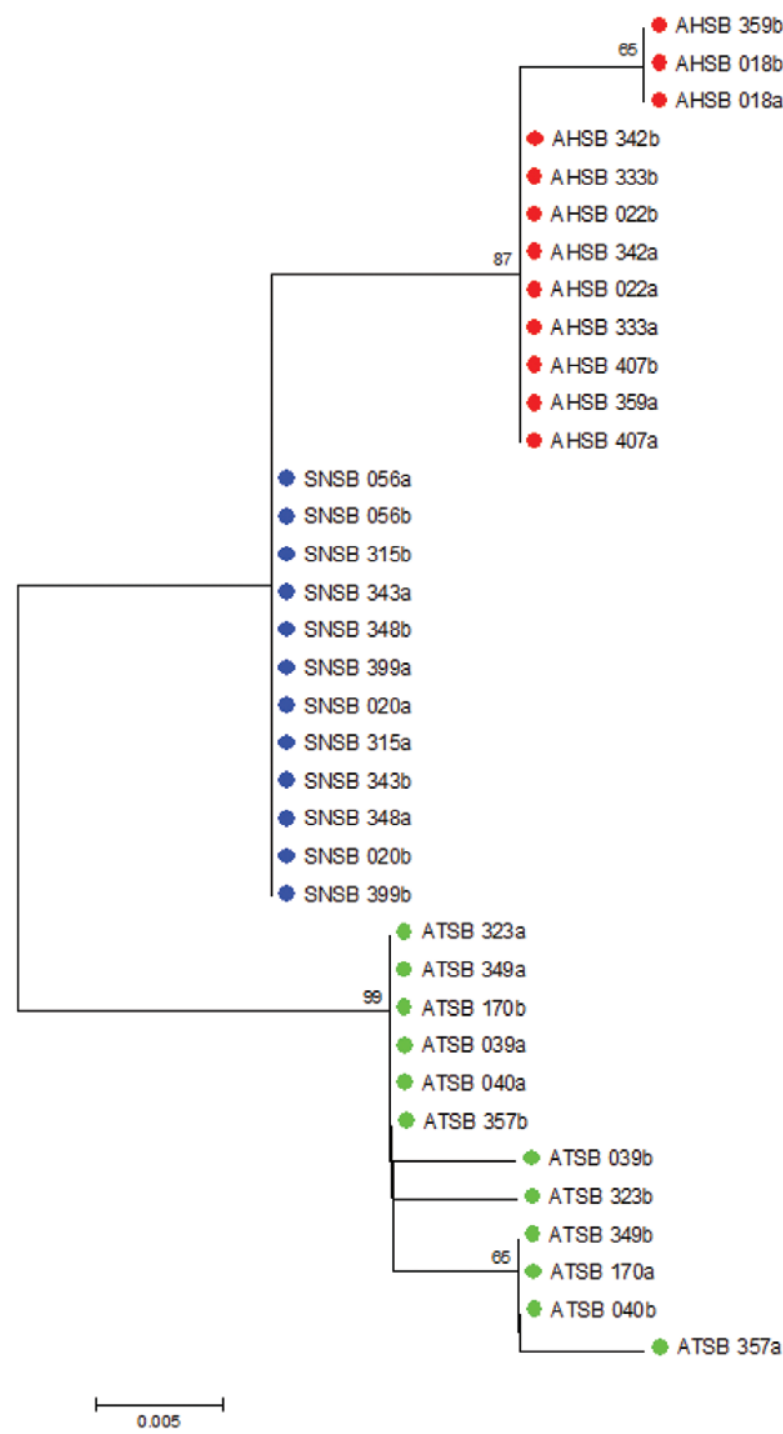

Fig. 2: neighbor-joining tree of the $c p r$ DNA sequences. The figure shows a neighbour-joining tree based on Anopheles triannulatus s.l. sequences of the $c p r$ gene obtained with Kimura two-parameters distance. Numbers on the nodes represent the percentage bootstrap values based on 1,000 replications. AHSB: Anopheles halophylus (red dot); ATSB: An. triannulatus s.s. (green); SNSB: An. triannulatus species C (blue). 


\section{REFERENCES}

Chadee DD, Wilkerson RC 2005. Anopheles triannulatus (Neiva \& Pinto): a new Anopheles record from Trinidad, West Indies. $J$ Am Mosq Control Assoc 21: 316-317.

Charlwood JD, Wilkes TJ 1981. Observations on the biting activity of Anopheles triannulatus bachmanni from the Mato Grosso, Brazil. Acta Amaz 11: 67-69.

Consoli RAGB, Lourenço-de-Oliveira R 1994. Principais mosquitos de importância sanitária no Brasil, Rio de Janeiro, Fiocruz, 225 pp.

Diabaté A, Dabire RK, Kim EH, Dalton R, Millogo N, Baldet T, Simard F, Gimnig JE, Hawley WA, Lehmann T 2005. Larval development of the molecular forms of Anopheles gambiae (Diptera: Culicidae) in different habitats: a transplantation experiment. J Med Entomol 42: 584-563.

Faran ME, Linthicum KJ 1981. A handbook of the Amazonian species of Anopheles (Nyssorhunchus) (Diptera, Culicidae). Mosq Syst 13: 1-81.

Filatov DA, Charlesworth D 1999. DNA polimorphism, haplotype structure and balancing selection in the Leavenworthia PgiC locus. Genetics 153: 1423-1434.

Forattini OP 1962. Entomologia médica, vol. 1, Faculdade de Higiene e Saúde Pública, São Paulo, 662 pp.

Galardo AK, Arruda M, D’Almeida Couto AA, Wirtz R, Lounibos LP, Zimmerman RH 2007. Malaria vector incrimination in three rural riverine villages in the Brazilian Amazon. Am J Trop Med Hyg 76: 461-469.

Galvão ALA 1941. Notas sobre alguns anofelíneos do sub-gênero Nyssorhynchus do norte do Brasil. Rev Biol Hyg 11: 92-96.

Hardin PE 2005. The circadian timekeeping system of Drosophila. Curr Biol 15: R714-22.

Hovemann BT, Sehlmeyer F, Malz J 1997. Drosophila melanogaster NADPH cytochrome P450 oxidoreductase: pronounced expression in antennae may be related to odorant clearance. Gene 189: 213-219.

Jowett T 1998. Preparation of nucleic acids. In DB Roberts, Drosophila, a practical approach, IL Press, Oxford, p. 347-371.

Kasai S, Tomita T 2003. Male specific expression of a cytochrome P450 (Cyp312a1) in Drosophila melanogaster. Biochem Biophys Res Commun 300: 894-900.

Koener JF, Carino FA, Feyereisen R 1993. The cDNA and deduced protein sequence of house fly NADPH-cytochrome $\mathrm{P} 450$ reductase. Insect Biochem Mol Biol 23: 439-447.

Kumar S, Tamura K, Nei M 2004. MEGA3: integrated software for Molecular Evolutionary Genetics Analysis and sequence alignment. Briefings Bioinform 5: 150-163.

Maibeche-Coisne M, Merlin C, François MC, Porcheron P, JacquinJoly E 2005. P450 and P450 reductase cDNAs from the moth Mamestra brassicae: cloning and expression patterns in male antennae. Gene 346: 195-203.

Myers MP, Wagner-Smith K, Wesley CS, Young MW, Seghal A 1995. Position cloning and sequence analysis of the clock gene, timeless. Science 270: 805-808.

Neiva A, Pinto C 1922. Considerações sobre o gênero Cellia Theobald, com a descripção de uma nova espécie. Brazil Med 36: 355-357.

Nikou D, Ranson H, Hemingway J 2003. An adult-specific CYP6 $\mathrm{P} 450$ gene is overexpressed in a pyrethroid-resistant strain of the malaria vector, Anopheles gambiae. Gene 318: 91-102.

Oliveira-Ferreira J, Lourenço-de-Oliveira R, Teva A, Deane LM, Daniel-Ribeiro CT 1990. Natural malaria infections in anophelines in Rondonia state, Brazilian Amazon. Am J Trop Med Hyg 43: 6-10.
Póvoa MM, Wirtz RA, Lacerda RNL, Miles MA, Warhurst D 2001. Malaria vectors in the municipality of Serra do Navio, state of Amapá, Amazon Region, Brazil. Mem Inst Oswaldo Cruz 96: 179-184.

Rona LDP, Carvalho-Pinto CJ, Gentile C, Grisard EC, Peixoto AA 2009. Assessing the molecular divergence between Anopheles (Kerteszia) cruzii populations from Brazil using the timeless gene: further evidence of a species complex. Malar J 8: 60 .

Rona LDP, Carvalho-Pinto CJ, Peixoto AA 2010. Molecular evidence for the occurrence of a new sibling species within the Anopheles (Kerteszia) cruzii complex in South-East Brazil. Malar J 9: 33.

Rosa-Freitas MG, Lourenço-de-Oliveira R, Carvalho-Pinto CJ, Flores-Mendoza C, Silva-do-Nascimento TF 1998. Anopheline species complexes in Brazil. Current knowledge of those related to malaria transmission. Mem Inst Oswaldo Cruz 93: 651-655.

Rozas J, Sánchez-DelBarrio JC, Messeguer X, Rozas R 2003. DnaSP, DNA polymorphism analyses by the coalescent and other methods. Bioinformatics 19: 2496-2497.

Rubio-Palis Y 1994. Variation of the vectorial capacity of some anophelines in western Venezuela. Am J Trop Med Hyg 50: 420-424.

Sakai T, Ishida N 2001. Circadian rhythms of female mating activity governed by clock genes in Drosophila. Proc Natl Acad Sci 98: 9221-9225.

Santos JM, Maia JF, Tadei WP 2004. Differentiation and genetic variability in natural populations of Anopheles (N.) triannulatus (Neiva \& Pinto, 1922) of Brazilian Amazonia. Braz J Biol 64: 327-336.

Santos JMM, Maia JF, Tadei WP, Rodriguez GAD 2003. Isoenzymatic variability among five Anopheles species belonging to the Nyssorhynchus and Anopheles subgenera of the Amazon Region, Brazil. Mem Inst Oswaldo Cruz 98: 247-253.

Santos JMM, Tadei WP, Contel EPB 1992. Biologia de anofelíneos amazônicos. XIV. Isoenzimas de esterase em Anopheles triannulatus (Neiva \& Pinto, 1922). Acta Amazonica 22: 219-228.

Silva-do-Nascimento T, Wilkerson RC, Lourenço-de-Oliveira R, Monteiro FA 2006. Molecular confirmation of the specific status of Anopheles halophylus (Diptera: Culicidae) and evidence of a new criptic species within An. triannulatus in central Brazil. $J$ Med Entomol 43: 455-459.

Silva-do-Nascimento TF, Lourenço-de-Oliveira R 2002. Anopheles halophylus, a new species of the subgenus Nyssorhynchus (Diptera: Culicidae) from Brazil. Mem Inst Oswaldo Cruz 97: 801-811.

Silva-do-Nascimento TF, Lourenço-de-Oliveira R 2007. Diverse population dynamics of three Anopheles species belonging to the Triannulatus Complex (Diptera: Culicidae). Mem Inst Oswaldo Cruz 102: 975-982.

Tadei WP, Dutary-Thatcher B 2000. Malaria vectors in the Brazilian Amazon: Anopheles of the subgenus Nyssorhynchus. Rev Inst Med Trop Sao Paulo 42: 87-94.

Tauber E, Roe H, Costa R, Hennessy JM, Kyriacou CP 2003. Temporal mating isolation driven by a behavioural gene in Drosophila. Curr Biol 13: 140-145.

Thompson JD, Gibson TJ, Plewniak F, Jeanmougin F, Higgins DG 1997. The ClustalX windows interface: flexible strategies for multiple sequence alignment aided by quality analysis tools. Nucleic Acids Res 25: 4876-4882.

Wang-Sattler R, Blandin S, Ning Y, Blass C, Dolo G, Touré YT, delle Torre A, Lanzaro GC, Steinmetz LM, Kafatos FC, Zheng L 2007. Mosaic genome architecture of the Anopheles gambiae species complex. PLoS ONE 2: e1249.

Wen Z, Scott JC 2001. Cytochrome P450 CYP6L1 is specifically expressed in the reproductive tissues of adult male German cockroaches, Blattella germanica (L.). Insect Biochem Mol Biol 31: 179-187. 


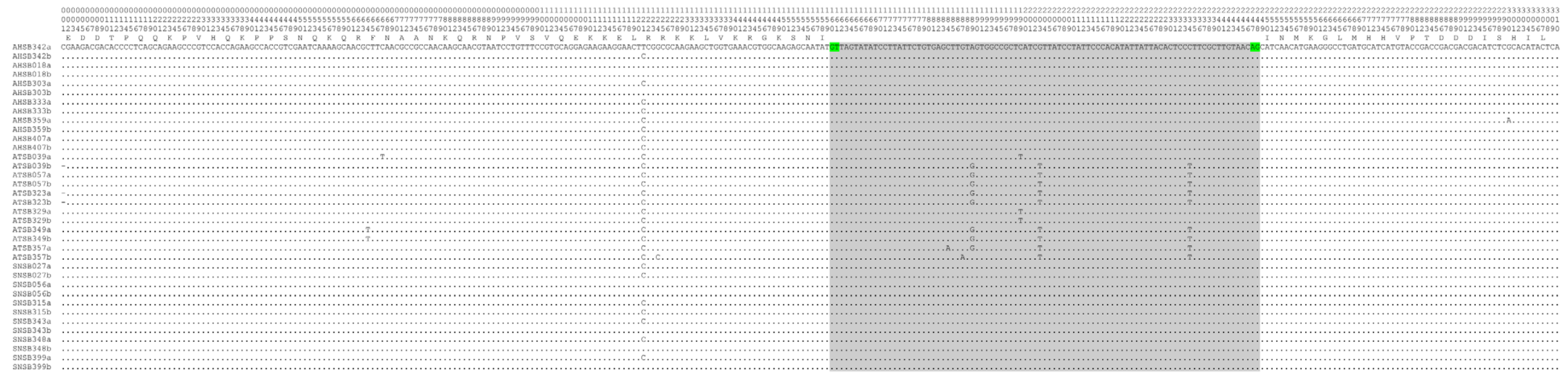

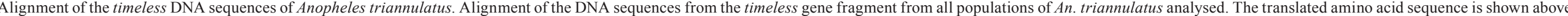
the alignment and the intron sequences are presented in the darkened regions. Dots represent identity to the first nucleotide sequence. AHSB: Anopheles halophylus; ATSB: An. triannulatus s.s.; SNSB: An. triannulatus species C.

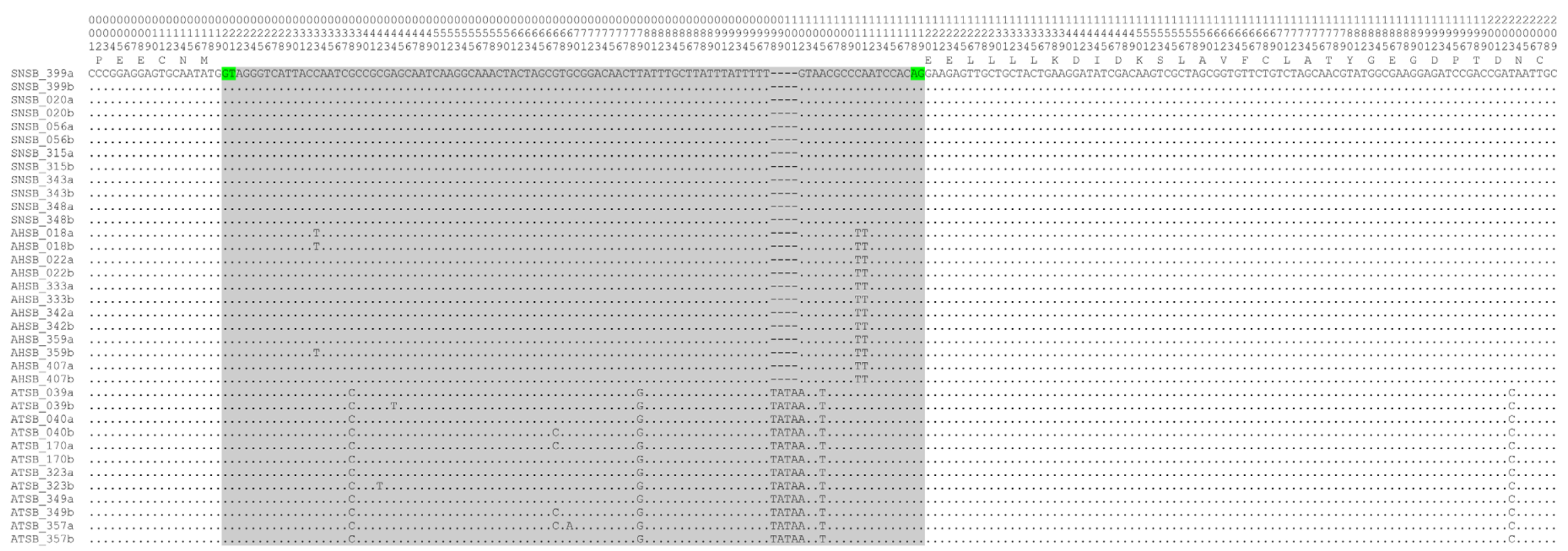

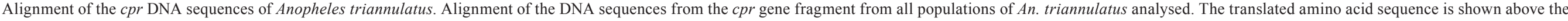
alignment and the intron sequences are presented in the darkened regions. Dots represent identity to the first nucleotide sequence. AHSB: Anopheles halophylus; ATSB: An. triannulatus s.s.; SNSB: An. triannulatus species C. 